\title{
COVID-19 pandemisinde kolostomili hastanın hemşirelik bakımı
}

\section{ÖZET}

Dünya Sağlık Örgütü tarafından COVID-19 tüm dünyaya yayılması ve binlerce insanın yaşamını yitirmesine neden olmasından dolayı 11 Mart 2020'de pandemi olarak ilan edildi. Hemşireler COVID-19 pandemisinde ön cephede yer almışlar ve sağlık bakım hizmetlerinin sunumunda fedakarca mücadele etmişler ve etmektedirler. Yaşadıkları tüm zorluklara rağmen COVID-19 tanılı veya hastalık şüphesi olan hastalara sağlı bakım hizmetini özverili bir şekilde vermektedirler. El hijyeni, sosyal mesafe ve maske kullanılmasının pandeminin kontrol altına alınmasında önemli olduğu bu süreçte, hemşirelerin "enfeksiyonları önleme ve kontrol rolü" ayrıca kritik önem taşımaktadır. $\mathrm{Bu}$ olgu sunumunda COVID-19 pandemisinde ostomisi olan hastanın bakımının önemine değinilmiştir.

Anahtar kelimeler: Bakım, hemşirelik, pandemi, stoma, COVID-19

Nursing care of a patient with colostomy in the COVID-19 pandemic

\begin{abstract}
COVID-19 was declared as a pandemic by the World Health Organization on March 11, 2020, due to the spread of COVID-19 all over the world and causing thousands of deaths. Nurses have been at the forefront of the COVID19 pandemic and have fought selflessly in the delivery of healthcare services. Despite all the difficulties they face, they provide health care services to patients diagnosed with COVID-19 or with suspected illness. In this process where hand hygiene, social distance and the use of masks are important in controlling the pandemic, the "infection prevention and control role" of nurses is also critical. In this case report, the importance of care of the patient with ostomy in the COVID-19 pandemic is emphasized.
\end{abstract}

Keywords: Care, nursing, pandemic, stoma, COVID-19

Geliş Tarihi: $11.02 .2021 \quad$ Kabul Tarihi:04.04.2021

aSBÜ Bakırköy Dr. Sadi Konuk Eğitim Araștırma Hastanesi, İstanbul, Türkiye, e-posta: birgul.odulozkaya@ gmail.com ORCID: 00000003-4414-3145

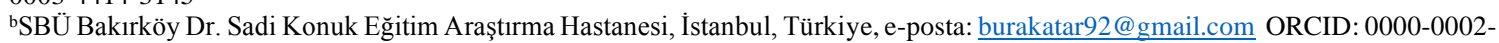
7396-4957

Sorumlu Yazar/Correspondence: Birgül Ödül Özkaya e-mail: birgul.odulozkaya@ gmail.com

Atıf: Ödül Özkaya B, Atar B. Covid 19 pandemisinde kolostomili hastanın hemşirelik bakımı. Sağlık ve Yaşam Bilimleri Dergisi 2021;3(1):111-114.

Citation: Odul Ozkaya B, Atar B. Nursing care of a patient with colostomy in the Covid 19 pandemic. Journal of Health and Life Science 2021;3(1):111-114. 


\section{GíRiş}

COVID-19 (koronavirüs) pandemisi küresel olarak bir sağlık krizine yol açmıştır ve Çin'in Hubei Eyaletine bağlı Wuhan şehrinde 2019 yılı Aralık ayında zatürre salgını ile başlamış ve tüm dünyaya yayılmıştır., ${ }^{1,2}$ Hemşireler COVID-19 pandemisinde ön cephede yer almışlar ve sağlık bakım hizmetlerinin sunumunda mücadele etmiş̧ler ve etmektedirler. ${ }^{3}$

Bulaşmanın önlenmesi, şüpheli vakaların ve hafif hastalıkları olanların evde izolasyonunu ve hastanelerde temas ve damlacık önlemlerini içeren sık1 enfeksiyon kontrol önlemlerini gerektirir. ${ }^{4}$ Hastalığın tedavisi veya önlenmesinde izolasyon ve destekleyici bakım önemlidir. ${ }^{5}$

COVID-19 pandemisini kontrol altına almak için; sık sık el hijyeni uygulanması, sosyal mesafeye uyulması ve maske kullanılmasının gerekli olduğu bu dönemde, hemşirelerin "enfeksiyonları önleme ve kontrol rolü" önemlidir. ${ }^{3}$ Dünya Sağlık Örgütü (DSÖ) 2020 yılını "Uluslararası Hemşire ve Ebe Yılı" olarak ilan etmiştir. ${ }^{6}$ Literatürde salgın durumlarında hemşirelerin mesleki risklerle karşılaşabileceklerinin farkında oldukları, kendilerinin yanısıra ailelerinin de güvenliği için endişe duydukları buna rağmen görev bilinciyle hasta bakımında fedakarca rol aldığ bildirilmektedir. $^{7}$ COVID-19 tanısı korulan hastalarda hemşirelik tanılarına göre hasta bakımında önceliklerin belirlenmesi, hümanistik, bütüncül ve bireyselleştirilerek bakımın verilmesi oldukça önemlidir. $^{6}$

COVID-19 hastalığında yaygın olan semptomlar ateş, kuru öksürük, boğaz ağrısı, kas ağrısı, yorgunluk ve nefes darlığıdır, baş ağrısı, hemoptizi, anosmi (koku alamama), bulantı, gastrointestinal kaynaklı kusma ve ishal nadir belirtiler arasındadır. ${ }^{2}$

Ostomi, dışkı veya idrarın bir stoma yoluyla karın bölgesine ağızlaştırılması için yapılan cerrahi bir prosedür olarak tanımlanabilir. Ostomili kişiler fiziksel sağlıklarının korunması ve yaşam kalitesinin arttırılması için özel bakıma ihtiyaç duyarlar. ${ }^{8} \mathrm{Bu}$ bağlamda COVID-19 hastalarında oksijenasyonu sağlamak için sıklıkla kullanılan prone pozisyonu ${ }^{9}$ ostomisi olan hastanın bakımında zorluğa neden olmaktadır. $\mathrm{Bu}$ olgu sunumunda Covid 19 pandemisinde ostomisi olan hastanın bakımının önemine değinilmiştir. Hastadan bilgilendirilmiş onam alınmıştır.

\section{OLGU}

63 yaşında erkek hastaya kolon kanseri ameliyatı sonrası kolostomi açıldı. Hastanın takibi sırasında PCR (Polymerase Chain Reaction- Polimeraz zincir reaksiyonu) testinin pozitif gelmesi üzerine izolasyon önlemleri alındı.
Hastanın fizik muayene bulgularında; batın rahat, öksürük, takipne, nemli cilt, bilinci non koopere olarak gözlendi. Hastanın fiziksel, psikolojik ve güvenli çevre açısından değerlendirmeleri yapıldı. Hastanın yapılan fizik muayenesinde yaşamsal bulguları; vücut sıcaklığı: 38,5 $\mathrm{C}^{0}$, kan basıncı: 110/70 mmHg, kalp hızı: $120 / \mathrm{dk}$, oksijen satürasyonu: $\% 85$, solunum sayısı: 26/dk olarak ölçüldü. Bilinç durumu değerlendirildi. COVID-19 hastalığına özgü belirti ve bulgular açısından izlendi.

Hemşirelik Tanıları: Hastanın ağrı, yorgunluk, bilgi eksikliği, stomaya uyumun sağlanmasında güçlük, beslenmeye ilişkin sorunlar, ölüm korkusu ve COVID19 pozitif olmasından dolayı bakım veren hemşirelere bulaş riski belirlenen tanılardır.

\section{Hemşirelik Bakımı}

- Güvenli çevrenin sağlanması için izolasyon önlemleri alındı, hasta odasının negatif basınç cihazı ile aralıklı temizlenmesi sağlandı. İzolasyonu sağlamak açısından refakatçı değișimi yapılamadı. COVID-19 hastalığının önlenmesinde el hijyeni, maske kullanımı ve sosyal mesafenin önemi hasta ve yakınına anlatıld1. Ayrica hastanın semptomlarında iyileşme sağlanana kadar solunum ve temas izolasyonu uyguland1. Ostomi bakımı yapılırken aynı zamanda hasta mahremiyeti korundu. Bakım veren hemşire kendisini de COVID-19 belirtileri açısından izledi.

- Hekim istemine göre nazal maske ile $2 \mathrm{lt} / \mathrm{dk}$ oksijen tedavisi uygulandı. Oksijen azlığı belirtileri ve oksijen tedavisinin komplikasyonları açısından hasta izlendi. Arteriyel kan gazı sonuçları değerlendirildi.

- Ağrısı için order edilen analjezikler uygulandı ve takip edildi.

- Covid 19 tanısından sonra hastada halsizlik ve iştahsızlık görüldü. Hastanın mobilizasyonu sağlanamadı. Beslenmesi total parenteral nutrisyon ve enteral mama desteği ile sağlandı.

- Hastanın psikolojik tepkisi duygusal ve bilişsel değişiklikleri değerlendirildi. Hastanın ölüm korkusu vardı. COVID-19 tanılı ve stoması olan hastaya ve ailesine psikolojik destek sağlandı. Hastanın duygularını ifade edebilmesi ve böylece rahatlaması sağlandı.

- Tüm kişisel koruyucu ekipmanlar hasta odasına girerken kullanıldı. Bu durum hasta ile iletişim kurmayı güçleştirdi. Hastanın odasında eskisinden daha kısa süre kalındığ 1 için, stoma eğitimi ayrıntılı olarak verilemedi. Eğitim verirken yüz yüzeden daha çok teknolojik aletlerden faydalanıldı. 
- Hastanın ihtiyacı olduğunda prone pozisyonu vermek stomadan dolayı güç oldu. Pozisyonu yastık ile desteklendi.

Takibinin beşinci gününde hastanın genel durumunun bozulması ve oksijen saturasyonunun düşmesi sonucunda hasta yoğun bakım ünitesine sevk edildi.

\section{TARTIŞMA}

Hastalar ve tıbbi personel için enfeksiyon riskini azaltmak için hastaların cerrahi tedavisi için en son yönergeleri takip etmek önemlidir. ${ }^{10}$ Coranovirüs ailesi, solunum yolu, gastrointestinal, hepatik ve kardiyovasküler sistemde birçok hastalığa neden olan, zarflı, tek sarmallı, bölünmemiş ribonükleik asit (RNA) virüsü sınıfındadır. ${ }^{2}$ COVID-19'da öksürük, solunum sıkıntısı ve hipertermi sık görülen belirtiler arasındadır. $^{1}$ Huang ve arkadaşları hastaların yarısından fazlasında nefes darlığı geliştiğini ve en sık; ateş, öksürük, kas ağrısı ve yorgunluk görüldüğünü bildirmişlerdir. ${ }^{11}$ Solunum hızının artması, öksürük ve oksijen satürasyonunun düşmesi nedeniyle solunum zorluğunda amaç solunum zorluğunu azaltmak ve hastanın rahatlamasını sağlamaktır. Solunum hızındaki değişiklikler, solunum zorluğu, solunum güçlüğü belirtileri ve yaşam bulguları değerlendirilir, hastaya nemlendirilmiş oksijen verilir, hastanın hidrasyonu korunur. ${ }^{4}$ Hastalarda akut solunum zorluğu durumunda akciğerlerdeki oksijenlenmeyi arttırmak için prone (yüzüstü) pozisyonu verilir., ${ }^{3,12}$

Hafif semptomları olan hastalarda, tercihen negatif basınçla iyi havalandırılan bir izolasyon odasının sağlanması, ateş düşürücü ilaçlar (örn. Asetaminofen), soğuk uygulama, oksijen uygulaması, besin takviyeleri ve antibakteriyel ilaç uygulamaları semptomatik ve destekleyici olarak yapılır. ${ }^{5}$

Hastalar eşlik eden bir hastalık varlığında daha kötü prognoz sergilemektedirler: herhangi bir ek hastalığ olmayan vakalarda vaka ölüm oranı \%0,9'a kadar düşerken, kardiyovasküler hastalıkta $\% 10,5$, diyabette $\%$ 7,3, kronik solunum yolu hastalığında \%7,3, hipertansiyonda $\% 6,0$ ve kanser vakalarında $\% 5,6{ }^{\prime}$ dır. $^{2}$ $\mathrm{Bu}$ olguda da kolon kanseri geçmişinin olması semptomlarını ağırlaşmasına neden olmuş olabilir.

Özel stoma bakımının sağlanması ameliyat öncesi dönemde başlar ve ameliyat sonrası ve rehabilitasyon dönemi ve hastanın yaşamı boyunca devam eder. ${ }^{8}$ Stoması olan bu hastamızda hemşirelik bakımı girişimlerini uygularken, hastanın ve yakının psikolojisinin bozulmasından dolayı stoma bakımına katılmak istemediler. Halsizlik ve yorgunluk şikayeti sebebiyle yeterince mobilizasyonu sağlanamadi. Prone pozisyonundan dolayı stoma kenarından sızıntı oldu. Günde birkaç defa adaptör torba değişimi yapıldı. Bu durum hemşirenin iş yükünü artırmış olup aynı zamanda bakım veren sağlıkçıların da bulaş riskini artırmıştır. $\mathrm{Bu}$ hastaya bakan hemşirelerden iki tanesi de COVID-19 tanısı almıştır. Bu nedenle, koruyucu tedbirlerin uygulanması, hastaların ve sağlık personelinin sağlık ve güvenliğini sağlamak için gerekli önlemlerdir. ${ }^{13}$ COVID-19 salgını sırasında hastalara güvenli ve etkili bakımı sağlamak için rehberler geliştirilmeli ve uygulanmalıdır. ${ }^{10}$

\section{SONUÇ}

Sonuç olarak, bu olguda COVID-19 pozitif olan stomalı hastanın bakımı diğer COVID-19 tanısı alan hastalardan daha kapsamlıdır. Hastanın bakımında özel dal hemşireliği olan stoma hemşiresinin de bulunması gerekmektedir.

\section{KAYNAKLAR}

1. WHO, Coronavirus disease (COVID-19) outbreak situation. World Health Organization 2020. https://www.who.int/emergencies/diseases/novelcoronavirus-2019.7. Accessed May 05, 2020.

2. Pamuk S, Özkan A, Polat B. Epidemiology, pathogenesis, diagnosis and management of COVID-19. Tr-ENT. 2020;30(Supp 1):1-9.

3. THD, COVID-19 Hemşire Eğitim Rehberi ve Bakım Algoritmaları, Türk Hemşireler Derneği. http://www.thder.org.tr/uploads/files/thdcovid2020-2.pdf. Erişim: 15 Mayıs 2020.

4. Sharma T, Ahvwal S. Managing Covid 19 patients: nurses role and considerations. Journal of Perioperative \& Critical Intensive Care Nursing. 2020;2(158):1-7.

5. Sharma SK, Nuttall C, Kalyani V, Hemlata. Clinical nursing care guidance for management of patient with COVID-19. Journal of Pakistan Medical Association 2020;70(5):S118-S123.

6. Göçmen Baykara Z, Eyuboglu G. COVID-19 pandemisinde hemşirelik bakımı. Gazi Sağlık Bilimleri Dergisi. 2020:9-17.

7. Fernandez R, Lord H, Halcomb E, et al. Implications for COVID-19: a systematic review of nurses' experiences of working in acute care hospital settings during a respiratory pandemic. Int J Nurs Stud. 2020; 111:103637.

8. Recalla S, English K, Nazarali R, Mayo S, Miller $\mathrm{D}$, Gray M. Ostomy care and management a systematic review. J Wound Ostomy Continence Nurs. 2013;40(5):489-500.

9. Özbilen F, Altunkan AA. COVID-19 ve uyanık pron pozisyon. Turk J Intensive Care. 2020;18:5056.

10. Al-Jabira A, Kerwana A, Nicolab M et al. Impact of the Coronavirus (COVID-19) pandemic on surgical practice-Part 1. International Journal of Surgery. 2020;79:168-179.

11. Huang C, Wang Y, Li X, et al. Clinical features of patients infected with 2019 novel coronavirus in Wuhan, China. Lancet. 2020;395:497-506.

12. COVID-19 (SARS-CoV-2 Enfeksiyonu) Rehberi Bilim Kurulu Çalışması, Türkiye Cumhuriyeti Sağlık Bakanlığı, Halk Sağlığı Genel Müdürlüğü. https://covid19bilgi.saglik.gov.tr/depo/rehberler/C OVID-19_Rehberi.pdf Erişim: 12 Mayıs 2020. 
13. Ren Y, Liu S, Yang L, et al. Practice and exploration of infection prevention and control measures based on risk management of surgical patients during the epidemic of corona virus disease 2019 (COVID-19). American Journal of Infection Control. 2021;49:151-157. 